московский политех

ТРАКТОРЫ И СЕЛЬХОЗМАШИНЫ Научно-практический журнал

\section{Выходит с 1930 года}

Ведущий журнал отрасли тракторного и сельскохозяйственного машиностроения, публикующий объективную и всеобъемлющую информацию на самые актуальные темы:

- создание новых машин и оборудования

для агропромышленного комплекса:

- проблемы регионального сельхозмашиностроения;

- эффективные отечественные и зарубежные технологии

- рынок сельскохозяйственной техники

- новости агросервиса;

- результаты испытания машин;

- фактические данные по качеству и надёжности с.-х. техники

- советы механизаторам

- предложения зарубежных фирм

Тракторы и сельхозмашины. № 4.202

Научное и техническое редактирование: к.Т..., проф. А.В. Лепёшкин Редактор: А.В. Куркова

Компьютерная верстка: Ю.С. Акульшина

Дизайн обложки: М.С. Кузьменко

Фотография на обложке взята из открытых источников

Подписано в печать 12.0921. Формат 60×90/8

Усл. печ. л. 8,8. Тираж 500 экз. Заказ № 79

Отпечатано в типографии Издательства Московского Политеха

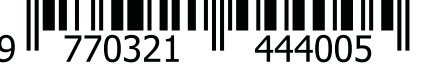

DO1: 10.31992/0321-4443-2021-4

WWW.MOSPOLYTECH.RU
Адрес издательства: 115280, г. Москва, ул. Автозаводская, 16

Сайт: www mospolytech.ru

E-mail: izdat.mospolytech@yandex.ru

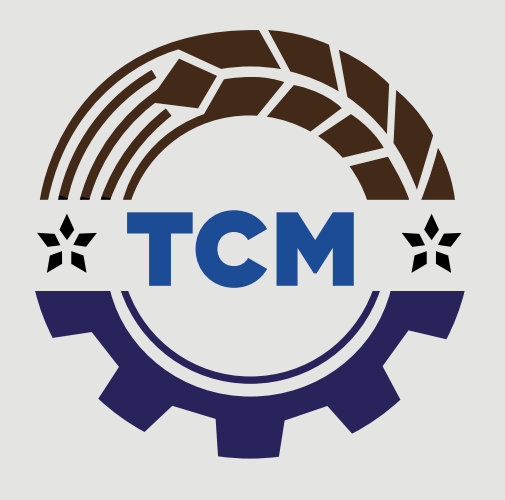

\section{TPAKTOPB]} И СЕЛЬХОЗМАШИНЫ

НАУЧНО-ПРАКТИЧЕСКИЙ ЖУРНАЛ

№ $4 \cdot 2021$
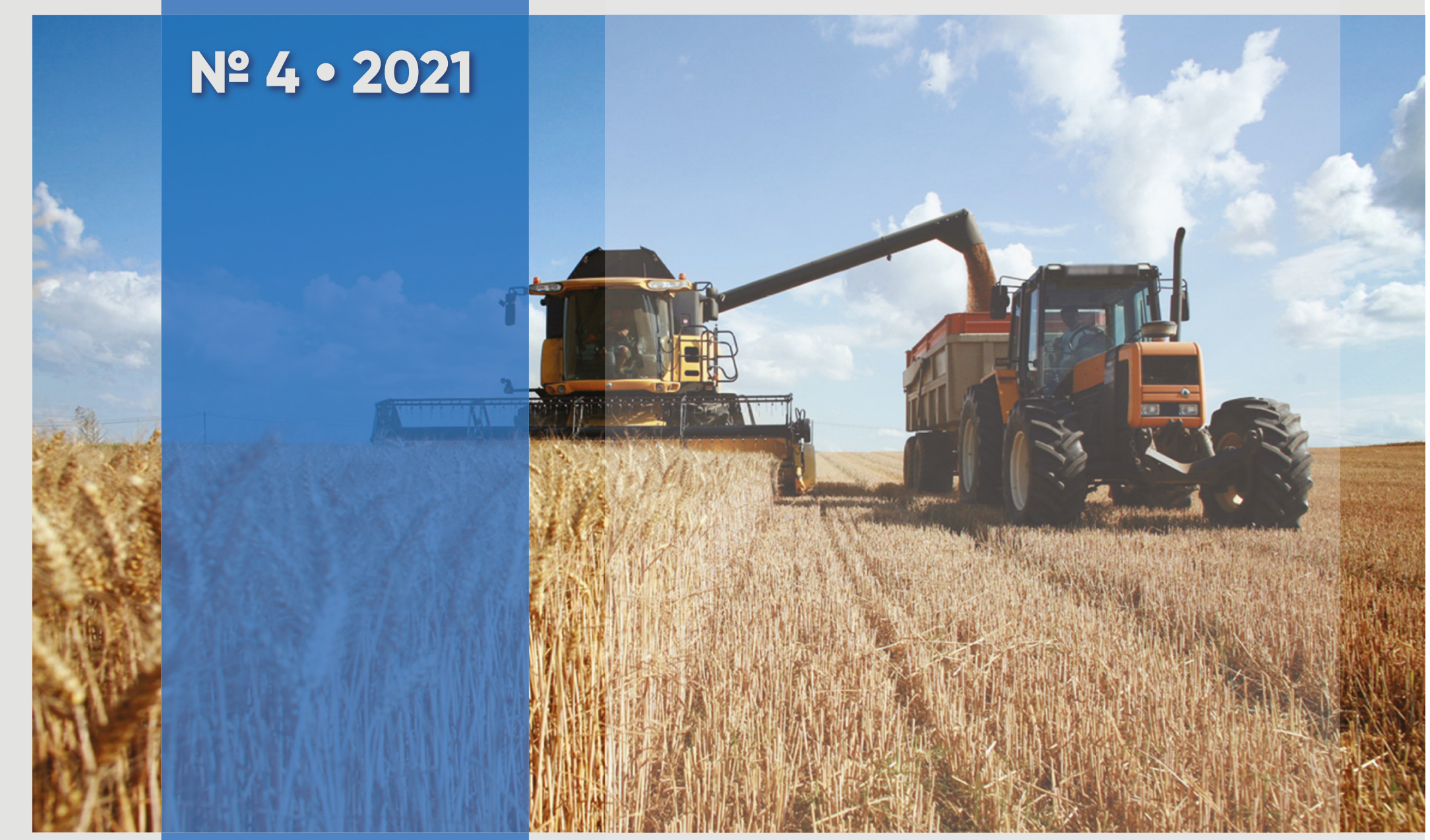

WWW.MOSPOLYTECH.RU

a)

ВЕДУЩИЙ ЖУРНАЛ ОТРАСЛИ ТРАКТОРНОГО

И СЕЛЬСКОХОЗЯЙСТВЕННОГО МАШИНОСТРОЕНИЯ 


\section{ГОДЖАЕВУ Захиду Адыгезаловичу - 70 лет}

8 августа 2021 г. исполнилось 70 лет известному российскому ученому

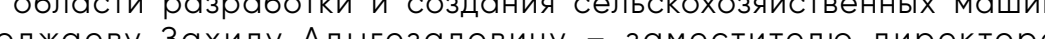
по инновационной и внедренческой деятельности Федерального государственного бюджетно но научного учреждения мФедеральный научный агроинженерный центр ВиМм, профессору Московского оехнических наук, профессору илену-корреспонденту РАН, цлору редколлегии нашего журнала.

З.А. Годжаев родился в городе Барда Азербайджанской ССР. В 1972 М им. М. Азизбекова в Баку. В1975-1 кандидатскуюдисскертацию по техническимнаукам.

в 1979-2002 гг. работал в Государстеннио научно-исспедовательском тракторном институте «НАТИ», где прошел путь до гпавного научного сотрудника. В 1994 г. защитил докторскую диссертацию.

В 2002-2014 гг. - генеральный директор «Федерального исследовательского испытательного центра сельскохозяйственного машиностроениям. С2014.понастойееврема - заместительдиректора

ПА. Гонда

3.А. Годжаев является автором более 250 научных трудов, монографий
и изобретений в области создания и исследования машиностроительных

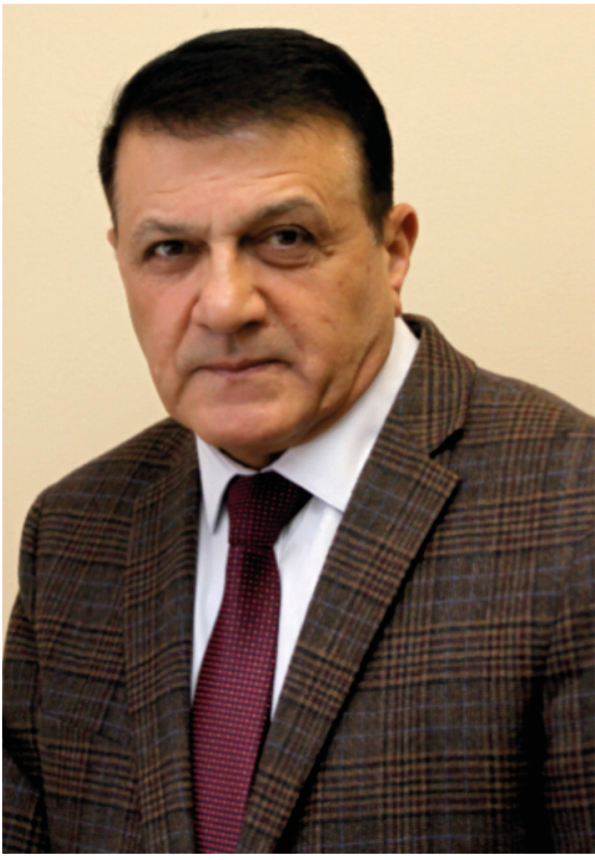
конструкций, информационных технологий, математического и компьютерного моделирования процессов. Под его


непосредственно участвовал и руководил НИОКР по созданию и совершенствованию тракторов Т-10, Т-170 (ЧТ3), Т-250 (АТЗ), Т-30, Т-40 (ВТ3), К-744 (ПТЗ), Т-15К (ХТЗ), автомобиля высокой проходимости ЗИЛ-13згя и другой автотракторнои техники, агрегатов и излов. Результаты

3.А. Годжаевым разработаны новые теории, методы моделирования и программные комплексы для оценки со сложными нелинейными кинематическими связями элементов конструкции и при случайных характерах внешних воздействий;

- создан и внедрен программно-математический комплекс «Многокритериальная оптимизация конструкций критериев качества иварьируемыхпаромететро

- решены вопросы создания высокоэффективных метопов и средств стендовых, полигонных и эксплустанионных испытаний для совершенствования сельскохозяйственных тракторов

- разработаны концептуальные схем

работу по созданию роботизированных мобильных энергетических обладающих повышенной прохооимостью и пониженным давлением на почву. В ФГБНУ ФНАЦ ВИМ руководит разработкой инновационной мобильной тягово-транспортной техники для сельского хозяйства, в том числе на автоматизированном электроприводе

3.А. Годжаев осуществляет преподавательскую деятельность и подготовку научных кадров в должности профессора в МГТУ им. Н.Э. Баумана, Московском Политехе и ФГБОУ ВО РГАЗУ. Им разработаны рабочие программы дисциплин "Статистическая динамика мобильных машин" и "Сельскохозяйственная робототехника». Является членом трех Под его научным руководством выполнен ряд кандидатских и докторских диссертащий по машиностроению иробототехнике.

С 2016 г. - член Научного совета по робототехнике и мехатронике РАН. В 2019 г. избран членом-корреспондентом (

Является координатором Российской технологической платформы «Инновационные машинные технологии сельского хозяйства", объединяющей более 45 организащий АПК РФ.

Член редколлегии журнала «Тракторы и сельхозмашины» и редакционного совета журнала «Арктика: инновационные 


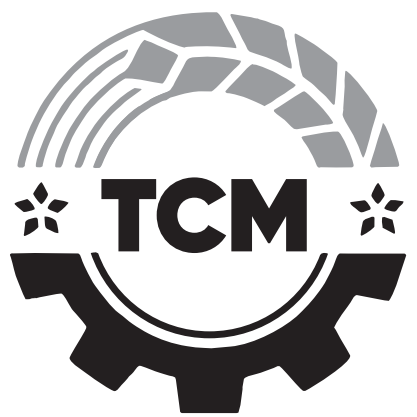

\section{TPAKTOPЫ И СЕЛЬХОЗМАШИНЫ}

TRACTORS AND AGRICULTURAL MACHINERY

\section{НАУЧНО-ПРАКТИЧЕСКИЙ ЖУРНАЛ}

Издается с февраля 1930 г.

\section{$4 \cdot 2021$}

Выходит 6 раз в год

ISSN 0321-4443

DOI: 10.31992/0321-4443-2021-4

\section{Учредитель}

- Федеральное государственное автономное образовательное учреждение высшего образования «Московский политехнический университет»

Зарегистрирован Федеральной службой по надзору в сфере связи, информационных технологий и массовых коммуникаций 14.04.2017 ПИ № ФС77-69443

Журнал входит в перечень ВАК РФ изданий для публикации трудов соискателей ученых степеней, а также в Российский индекс научного цитирования (РИНЦ)

\section{Издатель}

Московский Политех

Адрес издательства:

115280, Москва, Автозаводская, 16 Тел. (495) 276-33-67

E-mail: izdat.mospolytech@yandex.ru

Сайт: www.mospolytech.ru

Журнал распространяется по подписке, которую можно оформить в любом почтовом отделении по каталогу «Пресса России» - индекс 27863, а также в агентствах: «Информнаука», тел. (495) 787-38-73, gladkih@viniti.ru «Урал-Пресс», тел. (495) 789-86-36, e timoshenkova@ural-press.ru;

«МК-Периодика», тел. (495) 672-70-89, chernous@periodicals.ru

Перепечатка материалов из журнала возможна при обязательном письменном согласии редакции. При перепечатке ссылка на журнал «Тракторы и сельхозмашины» обязательна.

За содержание рекламных материалов ответственность несет рекламодатель.

За приводимые в статьях факты, точность расчетов и экспериментальных данных, а также за точность цитирования и ссылок на источники ответственность несут авторы. 


\section{ГЛАВНЫЙ РЕДАКТОР}

КАМИНСКИЙ Валерий Наумович - профессор, доктор технических наук; профессор Московского политехнического университета, член Экспертного совета ветеранов (старейшин) отрасли поршневого двигателестроения России; заслуженный работник промышленности Московской области (Москва, Россия)

\section{ОТВЕТСТВЕННЫЙ РЕДАКТОР}

ЛЕПЁШКИН Александр Владимирович - профессор, кандидат технических наук; профессор Московского политехнического университета, доцент Московского государственного технического университета имени Н.Э. Баумана (Москва, Россия)

\section{РЕДАКЦИОННАЯ КОЛЛЕГИЯ}

БАХМУТОВ Сергей Васильевич - профессор, доктор технических наук; заместитель генерального директора по научной работе Государственного научного центра РФ «Центральный научно-исследовательский автомобильный и автомоторный институт „НАМИ“» (Москва, Россия)

ГОДЖАЕВ Захид Адыгезалович - член-корреспондент РАН, профессор, доктор технических наук; заместитель директора по инновационной и внедренческой деятельности Федерального научного агроинженерного центра ВИМ (Москва, Россия)

гОРОДЕЦКИЙ Константин Исаакович - профессор, доктор технических наук; профессор Московского политехнического университета; заслуженный машиностроитель РФ (Москва, Россия)

ДЕВЯНИН Сергей Николаевич - профессор, доктор технических наук; профессор Российского государственного аграрного университета - МСХА (Московская сельскохозяйственная академия) имени К.А. Тимирязева (Москва, Россия)

ЕРОХИН Михаил Никитьевич - академик РАН, доктор технических наук; профессор Российского государственного аграрного университета - МСХА (Московская сельскохозяйственная академия) имени К.А. Тимирязева (Москва, Россия)

ЖАЛНИН Эдуард Викторович - профессор, доктор технических наук; заведующий отделом Федерального научного агроинженерного центра ВИМ; заслуженный деятель науки РФ (Москва, Россия)

ИЗМАЙЛОВ Андрей Юрьевич - академик РАН, доктор технических наук; директор Федерального научного агроинженерного центра ВИМ (Москва, Россия)

КОВАЛЁВ Михаил Михайлович - доктор технических наук; научный руководитель Федерального научного центра лубяных культур; заслуженный изобретатель РФ (Тверь, Россия)

КОТИЕВ Георгий Олегович - профессор, доктор технических наук; заведующий кафедрой Московского государственного технического университета имени Н.Э. Баумана; заслуженный деятель науки РФ (Москва, Россия)

КУТЬКОВ Геннадий Михайлович - профессор, доктор технических наук; профессор Российского государственного аграрного университета - МСХА (Московская сельскохозяйственная академия) имени К.А. Тимирязева; заслуженный деятель науки и техники РФ (Москва, Россия)

ЛАЧУГА Юрий Фёдорович - академик РАН, доктор технических наук; академик-секретарь Отделения сельскохозяйственных наук РАН, председатель Экспертного совета Отделения сельскохозяйственных наук РАН (Москва, Россия)

ЛОБАЧЕВСКИЙ Яков Петрович - академик РАН, доктор технических наук; первый заместитель директора Федерального научного агроинженерного центра ВИМ (Москва, Россия)

ЛЯШЕНКО Михаил Вольфредович - профессор, доктор технических наук; заведующий кафедрой Волгоградского государственного технического университета (Волгоград, Россия)

МАРЧЕНКО Андрей Петрович - профессор, доктор технических наук; проректор по научной работе НТУ ХПИ (Национальный технический университет «Харьковский политехнический институт»), заместитель главы Совета проректоров по научной работе ВУЗов Украины, академик Академии высшей школы Украины, член-корреспондент Инженерной академии Украины (Харьков, Украина)

НАТРИАШВИЛИ Тамаз Мамиевич - академик Национальной академии наук Грузии, профессор, доктор технических наук; директор Института механики машин им. Р. Двали (ИММ); лауреат Национальной премии Грузии в области науки (Тбилиси, Грузия) ПРЕДИГЕР Виктор - профессор, доктор технических наук; профессор Университета прикладных наук (Оснабрюк, Германия)

СКВОРцОВ Аркадий Алексеевич - профессор, доктор физико-математических наук; проректор по исследованиям и разработкам Московского политехнического университета (Москва, Россия)

СоловьЁв Рудольф Юрьевич - доцент, кандидат технических наук; директор Центра сельскохозяйственного машиностроения Государственного научного центра РФ «Центральный научно-исследовательский автомобильный и автомоторный институт „НАМИ“» (Москва, Россия)

СТАСИЛЕВИЧ Андрей Георгиевич - генеральный конструктор ОАО «МТЗ» (Минский тракторный завод) (Минск, Беларусь) ФОМИН Валерий Михайлович - профессор, доктор технических наук; профессор Московского политехнического университета, член Экспертного совета ветеранов (старейшин) отрасли поршневого двигателестроения России (Москва, Россия)

Фукс Кристиан - доктор технических наук; менеджер проекта по системам больших двигателей международной инжиниринговой компании AVL List (Anstalt für Verbrennungskraftmaschinen List - «Институт двигателей внутреннего сгорания „Лист“») (Грац, Австрия)

ШуМАН Олаф - генеральный директор ООО «ФЭВ Рус» международной инжиниринговой компании FEV (Forschungsgesellschaft für Energietechnik und Verbrennungsmotoren - «Исследовательская компания по силовым агрегатам и двигателям внутреннего сгорания») (Аахен, Германия) 


\section{EDITOR-IN-CHIEF}

Valery N. KAMINSKY - Professor, DSc in Engineering; Professor of Moscow Polytechnic University, Member of the Veterans (Elders) Expert Council of the Russian Piston Engine Industry; Honorary Worker of Industry of the Moscow Region (Moscow, Russia)

\section{EXECUTIVE EDITOR}

Alexander V. LEPESHKIN - Professor, PhD in Engineering; Professor of Moscow Polytechnic University, Associate Professor of Bauman Moscow State Technical University (Moscow, Russia)

\section{EDITORIAL BOARD MEMBERS}

Sergey V. BAKHMUTOV - Professor, DSc in Engineering; Professor, Deputy CEO for Research of the State Research Center of the Russian Federation NAMI (Moscow, Russia)

Zakhid A. GODZHAEV - Corresponding Member of the Russian Academy of Sciences, Professor, DSc in Engineering; Deputy Director for Innovation and Implementation Activities of the Federal Scientific Agroengineering Center VIM (Moscow, Russia)

Konstantin I. GORODETSKIY - Professor, DSc in Engineering; Professor of Moscow Polytechnic University; Honorary Mechanical Engineer of the Russian Federation (Moscow, Russia)

Sergey N. DEVYANIN - Professor, DSc in Engineering; Professor of Russian State Agrarian University - Moscow Timiryazev Agricultural Academy (Moscow, Russia)

Mikhail N. YEROKHIN - Full Member of the Russian Academy of Sciences, DSc in Engineering; Professor of Russian State Agrarian University - Moscow Timiryazev Agricultural Academy (Moscow, Russia)

Eduard V. ZHALNIN - Professor, DSc in Engineering; Head of the Department of the Federal Scientific Agroengineering Center VIM; Honorary Scientist of the Russian Federation (Moscow, Russia)

Andrey Yu. IZMAYLOV - Full Member of the Russian Academy of Sciences, DSc in Engineering; Director of the Federal Scientific Agroengineering Center VIM (Moscow, Russia)

Mikhail M. KOVALEV -DSc in Engineering; Research Advisor of the Federal Scientific Center for Bast Crops; Honorary Inventor of the Russian Federation (Tver, Russia)

George 0. KOTIEV - Professor, DSc in Engineering; Head of the Department of Bauman Moscow State Technical University; Honorary Scientist of the Russian Federation (Moscow, Russia)

Gennadiy M. KUTKOV - Professor, DSc in Engineering; Professor of Russian State Agrarian University - Moscow Timiryazev Agricultural Academy; Honorary Scientist of the Russian Federation (Moscow, Russia)

Yury F. LACHUGA - Full Member of the Russian Academy of Sciences, DSc in Engineering; Academician-Secretary of the Department of Agricultural Sciences of the Russian Academy of Sciences, Chairman of the Expert Council of the Department of Agricultural Sciences of the Russian Academy of Sciences (Moscow, Russia)

Yakov P. LOBACHEVSKIY - Full Member of the Russian Academy of Sciences, DSc in Engineering; First Deputy Director of the Federal Scientific Agroengineering Center VIM (Moscow, Russia)

Mikhail V. LYASHENKO - Professor, DSc in Engineering; Head of the Department of Volgograd State Technical University (Volgograd, Russia)

Andriy P. MARCHENKO - Professor, DSc in Engineering; Vice-Rector for Scientific-and-Research Work of National Technical University Kharkiv Polytechnic Institute; Deputy Head of the Council of Vice-Rectors for Scientific and Research Work of Universities of Ukraine, Full Member of the Academy of Higher School of Ukraine, Corresponding Member of the Engineering Academy of Ukraine (Kharkiv, Ukraine)

Tamaz M. NATRIASHVILI - Full Member of the Georgian National Academy of Sciences, Professor, DSc in Engineering; Director of Rafiel Dvali Institute of Machine Mechanics (IMM); Laureate of the Georgian National Prize in Science (Tbilisi, Georgia)

Viktor PREDIGER - Professor, DSc in Engineering (Dr.-Ing.); Professor of Osnabrück University of Applied Sciences (Osnabrück, Germany)

Arkadiy A. SKVORTSOV - Professor, DSc in Physics and Mathematics; Vice-President for Research and Development of Moscow Polytechnic University (Moscow, Russia)

Rudolf Yu. SOLOVYEV - Associate Professor, PhD in Engineering; Director of the Center for Agricultural Engineering at the State Research Center of the Russian Federation NAMI (Moscow, Russia)

Andrey G. STASILEVICH - General Designer of Minsk Tractor Works (Minsk, Belarus)

Valeriy M. FOMIN - Professor, DSc in Engineering; Professor of Moscow Polytechnic University; Member of the Veterans (Elders) Expert Council of the Russian Piston Engine Industry (Moscow, Russia)

Christian FUCHS - DSc in Engineering; Project Manager for Large Engine Systems, International Engineering Company AVL List (Anstalt für Verbrennungskraftmaschinen List) (Graz, Austria)

Olaf SCHUMANN - CEO of LLC FEV Rus, International Engineering Company FEV (Forschungsgesellschaft für Energietechnik und Verbrennungsmotoren) (Aachen, Germany) 


\section{НОВЫЕ МАШИНЫ И ОБОРУДОВАНИЕ}

Киреев И.М., Коваль З.М., Зимин Ф.А.

Обеспечение режимов работы высевающего аппарата специализированным оборудованием

\section{ТЕОРИЯ, КОНСТРУИРОВАНИЕ, ИСПЫТАНИЯ}

Грунин К.Е.

Совершенствование диагностики цилиндропоршневой группы методом пневмотестирования

Годжаев З.А., Шеховцов В.В., Ляшенко М.В. , Мерляк В.К., Филиппов Н.В.

Формирование динамической системы стенда для испытания трансмиссий на этапе проектирования

Сенькевич С.Е., Ильченко Е.Н., Алексеев И.С. Результаты проведения экспериментальных исследований трактора, оснащенного упругодемпфирующим механизмом при агрегатировании с сеялкой

\section{КАЧЕСТВО, НАДЕЖНОСТЬ}

Крохта Г.М., Хомченко Е.Н., Усатых Н.А.

Методика численного решения задач применительно к электротеплообменникам типа «змеевик»

для подогрева топлива

\section{ЭКОНОМИКА, ОРГАНИЗАЦИЯ И ТЕХНОЛОГИЯ ПРОИЗВОДСТВА}

Искендерзаде Э.Б., Аббасов Б.А., Ахмедли Ш.В., Исламова У.Р.

Обоснование формы и параметров новых сортировочных устройств для зернистых материалов

Кисель Ю.Е., Симохин С.П., Мурачев С.А.

Интенсификация восстановления деталей гидроаппаратуры железнением в потоке электролита

\section{Солонщиков П.Н.}

Исследование непрерывного режима смешивания кормовых компонентов в смесительной установке

\section{NEW MACHINES AND EQUIPMENT}

Kireev I.M., Koval' Z.M., Zimin F.A.

Ensuring the operating modes of the seeding apparatus 6 specialized equipment

\section{THEORY, DESIGN, TESTING}

\section{Grunin K.E.}

Improving diagnostics of the cylinder-piston group by pneumatic testing

Godzhayev Z.A., Shekhovtsov V.V., Lyashenko M.V., Merlyak V.K., Filippov N.V. Formation of the dynamic system of the test bench for transmissions at the design stage

Sen'kevich S.E., II'chenko YE.N., Alekseyev I.S. Results of experimental studies of a tractor equipped with an elastic-damping mechanism when aggregated with a seeder

Krokhta G.M., Khomchenko YE.N., Usatykh N.A. Methodology for the numerical solution of problems in relation to the coil-type electric heat exchangers for heating fuel

\section{ECONOMICS, ORGANIZATION AND TECHNOLOGY OF MANUFACTURING}

Isgandarzada E.B., Abbasov B.A., Ahmadl SH.V., Islamova U.R. Justification of the form and parameters of the new sorting device for grain materials

Kisel' YU.E., Simokhin S.P., Murachev S.A. Intensification of the recovery of hydraulic equipment parts by iron in the electrolyte flow

Solonshchikov P.N.

Study of the continuous mode of mixing feed components in a mixing plant 


\title{
Дорогие орузья!
}

Четвертым номером за 2021 год мы продолжаем движение в направлении совершенствования журнала «Тракторы и сельхозмашины» в части соответствия требованиям международных наукометрических баз данных с целью индексации в МНБД Scopus и Web of Science. Коллективом издания сделано уже многое. Сейчас разрабатывается новый сайт.

Среди наших сильных сторон - ритмичность и периодичность выпусков. Мы хотим создать хороший издательский портфель журнала. Просим вас продолжать и наращивать публикации в издании, а также вовлекать в этот процесс коллег из ваших сетевых контактов.

На третьей странице обложки номера мы публикуем материал, посвященный юбилею известного российского ученого в области разработки и создания сельскохозяйственных машин Годжаева Захида Адыгезаловича - заместителя директора по инновационной и внедренческой деятельности Федерального научного агроинженерного центра ВИМ, члена редколлегии и одного из самых активных авторов нашего журнала.

Поздравляем юбиляра и желаем ему счастья, здоровья, а также больших успехов в научной, инженерной и педагогической деятельности!

\author{
В.Н. Каминский, \\ д.т.н., профессор, главньій редактор \\ журнала «Тракторы и сельхозмашиныл»
}

EDITOR-IN-CHIEF'S COLUMN

\section{Dear friends!}

The fourth issue of year 2021 continues our movent towards improving Tractors and Agricultural Machinery journal in terms of compliance with the requirements of the international scientometric databases for the purpose of indexing in Scopus and Web of Science. The staff of the journal has already done a lot. A new website is currently being developed.

Among our strengths are the rhythm and frequency of issues publishing. We want to build a good publishing portfolio for the journal. We ask you to continue and increase publications in the journal, as well as to encourage colleagues from your personal network in this process.

The third page of the cover of this issue includes a material dedicated to the anniversary of the famous Russian scientist in the field of development and creation of agricultural machinery Zakhid A. Godzhaev, Deputy Director for Innovation and Implementation Activities of the Federal Scientific Agroengineering Center VIM, Editorial Board Member and one of the most active authors of our journal.

We congratulate the anniversary celebrant and wish him happiness, health, as well as great success in scientific, engineering and teaching activities!

Valery N. Kaminskiy,

DSc in Engineering,

Editor-in-Chief of the Tractors and Agricultural Machineryjournal

\section{РЕФЕРАТЫ СТАТЕЙ,}


НОВЫЕ МАШИНЫ И ОБОРУДОВАНИЕ NEW MACHINES AND EQUIPMENT

DOI: $10.31992 / 0321-4443-2021-4-6-12$

\section{Обеспечение режимов работы высевающего аппарата специализированным оборудованием}

\section{Ensuring the operating modes of the seeding apparatus by specialized equipment}

д.т.н. Киреев И.М., к.т.н. Коваль 3.М., Зимин Ф.А.

Новокубанский филиал ФГБНУ «Росинформагротех» (КубНИИТиМ), Новокубанск, Россия

zinakoval@mail.ru
I.M. Kireev, DSc in Engineering

Z.M. Koval, $\mathrm{PhD}$ in Engineering F.A. Zimin

Novokubansk Branch of Federal State

Budgetary Scientific Institution

Rosinformagrotekh (KubNIITiM),

Novokubansk, Russia

zinakoval@mail.ru

Предметом исследования является процесс высева семян высевающим аппаратом и показатели качества их распределения в рядок. Цель исследований - обоснование рационального технологического процесса распределения семян пропашных культур в рядок пневматическим высевающим аппаратом. Применялось специальное оборудование в системе обеспечения оборотов высевающего диска, присасывания семян к его отверстиям, пневмотранспорта семян после отделения от отверстия высевающего диска для контактного взаимодействия с приемной площадкой датчика числа семян и осаждения в сборнике. Новизна исследований заключается в применении акустического датчика единичной регистрации высеваемых высевающим аппаратом семян с малым промежутком времени, позволяющего проводить оценку качества работы высевающего аппарата по среднеквадратическому отклонению семян от заданной нормы их высева в нормальном их распределении в соответствии с законом больших чисел. Режим работы пневматического высевающего аппарата с применением специализированного оборудования в составе испытательного стенда осуществлялся на примере высева семян подсолнечника с нормой высева 3 шт./пог. м для условной скорости движения сеялки 9 км/ч. Полученные данные с различными промежутками времени между регистрируемыми семенами в формате *.WAV программой «РTC Mathcad Prime» представлялись классовыми распределениями семян в графическом виде и данными в табличной форме. Качественные показатели семян для посева и их классовое распределение в рядок рациональными режимами работы высевающего аппарата, оцениваемые специализированным оборудованием при применении закона больших чисел, являются основой научных исследований по прогнозированию урожайности пропашных культур.

Ключевые слова: высевающий аппарат, специальное оборудование, датчик, единичная регистрация семян, подсолнечник, распределение.

The subjects of the research are the process of sowing seeds with a seeding apparatus and the indicators of quality of their distribution in a row. The goal is to substantiate a rational technological process of distributing row crops seeds in a row with a pneumatic seeding apparatus. Special equipment was used in the system of ensuring the revolutions of the seeding disc, sucking seeds to its holes, pneumatic transport of seeds after separation from the opening of the seeding disc for contact interaction with the receiving platform of the sensor of the number of seeds and its settling in 
the collector. The novelty of the research lies in the use of an acoustic sensor for a single registration of the sowed seeds with a short time interval, which makes it possible to assess the quality of the operation of the sowing device by the standard deviation of seeds from a given seeding rate in their normal distribution in accordance with the law of numbers. The operating mode of the pneumatic seeding apparatus from specialized equipment as part of the test bench was carried out as an example of sowing sunflower seeds with a seeding rate of 3 seeds / linear meter for the conventional seeder speed of $9 \mathrm{~km} / \mathrm{h}$. The data obtained with different time intervals between the registered seeds in WAV format by the PTC Mathcad Prime software was represented by classical distributed seeds in graphical form and data in tabular form. The quality indicators of seeds for sowing and their class distribution in a row by rational operating modes of the seeding apparatus, assessed by specialized equipment when applying the law of large numbers, are the basis of scientific research on predicting the yield of row crops.

Keywords: seeding apparatus, special equipment, sensor, single seeds registration, sunflower, distribution

Для цитирования: Киреев И.М., Коваль З.М., Зимин Ф.А. Обеспечение режимов работы высевающего аппарата специализированным оборудованием // Tракторы и сельхозмашины. 2021. № 4. C. 6-12. DOI: 10.31992/0321-4443-2021-4-6-12

Cite as: I.M. Kireev, Z.M. Koval', F.A. Zimin Ensuring the operating modes of the seeding apparatus specialized equipment. Traktory i sel'khozmashiny. 2021. No 4, pp. 6-12 (in Russ.). DOI: 10.31992/0321-4443-2021-4-6-12

\section{ТЕОРИЯ, КОНСТРУИРОВАНИЕ, ИСПЫТАНИЯ}

THEORY, DESIGN, TESTING

DOI: 10.31992/0321-4443-2021-4-13-21

\section{Совериенствование диагностики цилиндропоршневой группы методом пневмотестирования}

\section{Improving diagnostics of the cylinder-piston group by pneumatic testing}

Грунин К.Е.

Нижегородский государственный

инженерно-экономический университет,

Княгинино, Россия

konst.grunin2010@yandex.ru
K.E. Grunin

Nizhny Novgorod State Engineering and

Economic University,

Knyaginino, Russia

konst.grunin2010@yandex.ru

Задачей нашего исследования является определение возникающих неплотностей при подаче сжатого воздуха в надпоршневое пространство под давлениями 4,5 и 6 кгс/см ${ }^{2}$, соответственно.

Для получения более достоверных результатов замеры неплотности надпоршневого пространства путём пневмотестирования должны производится трёхкратно, а оценивать изношенность данного трибосопряжения следует по средним значениям полученных величин.

Для того что бы выявить аналитические зависимости между показаниями пневмотестора и различными видами неисправностей цилиндра необходимо, в процессе проведения эксперимента, смоделировать наиболее часто встерчающиеся при рядовой эксплуатации двигателя неисправности, которые влияют на герметичность камеры сгорания.

Запланированные экспериментальные исследования проводились в чётком соответствии с поставленными задачами и включали три этапа:

Первый этап включал в себя сбор и анализ статистических данных по зависимости пока- 
заний пневмотестирования двигателей от различных типов неисправностей цилиндропоршневой группы (ЦПГ) при рядовой эксплуатации, а так же пневмотестирование цилиндров двигателей идущих в капитальный ремонт и микрометраж их ЦПГ.

На втором этапе проводился эксперимент по моделированию неисправностей на изготовленной экспериментальной установке и на рабочем двигателе, а так же определение влияния на показания пневмотестора соотношения неплотностей в сопряжении «поршень-кольцогильза».

Третий этап включал в себя обработку статистических данных, обработку данных полученных непосредственно во время проведения эксперимента с введёнными неисправностями ЦПГ и обработку данных полученных при определении влияния на показания пневмотестора соотношения неплотностей в сопряжении «поршень-кольцо-гильза».

Ключевые слова: двигатель внутреннего сгорания, ичилиндро-поршневая группа, пневмотестор.

The task of author's research was to determine the emerging leaks when compressed air is supplied to the above-piston space under pressure of 4,5 and $6 \mathrm{kgf} / \mathrm{cm}^{2}$, respectively.

To obtain more reliable results, measurements of the leakage of the above-piston space by pneumatic testing should be performed three times. The deterioration of this tribo-coupling should be assessed by the average values of the obtained values.

In order to identify the analytical relationships between the readings of the pneumotester and various types of cylinder malfunctions, it is necessary, to simulate during the experiment the malfunctions most often encountered during ordinary engine operation that affect the tightness of the combustion chamber.

The planned experimental studies were carried out in strict accordance with the tasks and included three stages.

The first stage included the collection and analysis of statistical data on the dependence of engine pneumatic testing indications on various types of cylinder-piston group (CPG) malfunctions during ordinary operation, as well as pneumatic testing of engine cylinders undergoing major repairs and their CPG micrometer size.

At the second stage, an experiment to simulate malfunctions on an experimental setup and on a working engine, as well as to determine the influence on the readings of the pneumatic tester of the ratio of leaks in the "piston-ring-sleeve" interface was carried out.

The third stage included the processing of statistical data, processing of the data obtained directly during the experiment with the introduced CPG malfunctions and the processing of the data obtained when determining the influence of the leakage ratio in the "piston-ring-sleeve" interface on the readings of the pneumatic tester.

Keywords: internal combustion engine, cylinder-piston group, pneumotester.

Для цитирования: Грунин К.Е. Совершенствование диагностики цилиндропоршневой группы методом пневмотестирования // Тракторы и сельхозмашиныл. 2021. № 4. С. 13 21. DOI: $10.31992 / 0321-4443-2021-4-13-21$

Cite as: K.E. Grunin Improving diagnostics of the cylinder-piston group by pneumatic testing. Traktory i sel'khozmashiny. 2021. No 4, pp. 13-21 (in Russ.). DOI: 10.31992/0321-44432021-4-13-21 
Рефераты статей.

DOI: $10.31992 / 0321-4443-2021-4-22-32$

\section{Формирование динамической системы стенда для испытания трансмиссий на этапе проектирования}

\section{Formation of the dynamic system of the test bench for transmissions at the design stage}

Член-корр. РАН, д.т.н. Годжаев 3.А. ${ }^{\text {, }}$ д.т.н. Шеховцов В.В. ${ }^{2}$, д.т.н. Ляшенко М.В. ${ }^{2}$, Мерляк В.К. ${ }^{2}$, Филиппов Н.В.

${ }^{1}$ ФГБНУ «Федеральный научный агроинженерный центр (ВИМ)», Москва, Poсcия,fic51@mail.ru

${ }^{2}$ ФГБОУ ВО «Волгоградский государственный технический университет» (ВолгГТУ), Волгоград, Россия shehovtsov@vstu.ru
Z.A. Godzhayev ${ }^{1}$, DSc in Engineering, Corresponding member of the Russian Academy of Sciences

V.V. Shekhovtsov ${ }^{2}$, DSc in Engineering

M.V. Lyashenko ${ }^{2}$, DSc in Engineering

V.K. Merlyak ${ }^{2}$,

N.V. Filippov ${ }^{2}$

${ }^{1}$ Federal Agroengineering Center VIM, Moscow, Russia,fic51@mail.ru,

${ }^{2}$ Volgograd State Technical University,

Volgograd, Russia

shehovtsov@vstu.ru

В материалах статьи анализируется проблема несоответствия динамических свойств трансмиссии испытательного стенда и трансмиссии реальной машины, вследствие чего при воспроизведении на стенде нагрузок динамического характера в ряде случаев после испытаний получаются результаты, не соответствующие результатам эксплуатации. Существенно отличаются обычно состав и схема передачи силового потока, а также упруго-инерционные параметры элементов упомянутых трансмиссий. Так, в состав стендов для испытания трансмиссий обычно не включают ходовую систему машины, подвеску и ряд других узлов и агрегатов; привод испытательного стенда также обычно осуществляется электрической машиной, а не двигателем внутреннего сгорания. В эксплуатации на динамическую нагруженность трансмиссии машины оказывает влияние совместная работа каждого из ее узлов, имеющего прямое или косвенное влияние на прохождение силового потока через трансмиссию. При стендовых же испытаниях в режиме переменных нагрузок на эту нагруженность оказывает влияние совместная работа испытуемой трансмиссии с узлами трансмиссии стенда, имеющими иные динамические характеристики. Авторами предложена описываемая в статье методика, позволяющая на стадии проектирования формировать совокупность динамических параметров элементов стенда таким образом, чтобы динамические свойства трансмиссии стенда соответствовали динамическим свойствам трансмиссии реальной машины. Предложен способ сближения динамической нагруженности трансмиссий на стенде и в составе реальной машины за счет целенаправленного формирования на этапе проектирования собственных частотных характеристик трансмиссии стенда таким образом, чтобы они в максимальной степени соответствовали характеристикам трансмиссии машины. Для этого за счет варьирования величин инерционных масс и упругих связей элементов трансмиссий стендов формируются спектры их собственных частот таким образом, чтобы в их валопроводах на режимах, на которых накапливается основная часть усталостных повреждений, формировалась сходная с наблюдаемой в трансмиссии реальной машины картина крутильных колебаний.

Ключевые слова: стендовые испытания трансмиссий, динамическая система стенда, динамическая система реальной машины, методика приближения условий нагружения на стенде к условиям эксплуатации.

The problem of the discrepancy between the dynamic properties of the transmission on the test bench and the transmission of production vehicle was analyzed. When the loads of a dynamic nature are reproduced on the test bench, in a number of cases, after tests, there are obtained the results 
that do not correspond to the results of its operation. Usually the composition and scheme of the power flow transmission, as well as the elastic-inertial parameters of the elements of the mentioned transmissions, differ significantly. The test bench for transmissions usually does not include the chassis of vehicle, suspension and a number of other components and assemblies. The test bench is also usually driven by an electric machine rather than an internal combustion engine. During operation the dynamic loading of the vehicle's transmission is influenced by the joint work of each of its units, which has a direct or indirect effect on the passage of the power flow through the transmission. In the mode of variable loads of bench tests, this loading is influenced by the joint operation of the tested transmission with the transmission units of the test bench, which have different dynamic characteristics. The authors proposed the method, which allows at the design stage to form a set of dynamic parameters of the stand elements in such a way that the dynamic properties of the stand transmission correspond to the dynamic properties of the transmission of a production vehicle. There was offered a method for converging the dynamic loading of transmission on the test bench and as part of a production vehicle due to the purposeful formation at the design stage of the intrinsic frequency characteristics of the test bench transmission so that they correspond to the maximum extent to the characteristics of the vehicle transmission. The varying of the values of the inertial masses and elastic connections of the transmission elements of the test benches, the spectra of their natural frequencies are formed in such a way that in shaft line on modes, when the main part of fatigue damage accumulates, a picture of torsional vibrations is similar to those observed in the transmission of a production vehicle.

Keywords: bench tests of transmissions, dynamic system of the bench, dynamic system of a production vehicle, technique for approximating loading conditions on the bench to operating conditions.

Для цитирования: Годжаев 3.А., Шеховцов В.В., Ляшенко М.В., Мерляк В.К., Филиппов Н.В. Формирование динамической системы стенда для испытания трансмиссий на этапе проектирования // Tракторы и сельхозмашины. 2021. № 4. C. 22-32. DOI: 10.31992/0321-4443-2021-4-22-32

Cite as: Z.A. Godzhayev, V.V. Shekhovtsov, M.V. Lyashenko, V.K. Merlyak, N.V. Filippov For-mation of the dynamic system of the test bench for transmissions at the design stage. Traktory i sel'khozmashiny. 2021. No 4, pp. 22-32 (in Russ.). DOI: 10.31992/0321-4443-20214-22-32

DOI: 10.31992/0321-4443-2021-4-33-44

\section{Результаты проведения экспериментальных исследований трактора, оснащенного упруго-демпфирующим механизмом при агрегатировании с сеялкой}

\section{Results of experimental studies of a tractor equipped with an elastic- damping mechanism when aggregated with a seeder}

к.т.н. Сенькевич С.Е.,

Ильченко Е.Н.,

Алексеев И.С.

ФГБНУ ФНАЦ ВИМ, Москва, Россия

sergej_senkevich@mail.ru
S.E. Senkevich, $\mathrm{PhD}$ in Engineering

Ye.N. Ilchenko,

I.S. Alekseyev

Federal Agroengineering Center VIM, Moscow, Russia

sergej_senkevich@mail.ru

Одним из существенных факторов, оказывающих влияние на работу трактора, является неустановившаяся нагрузка, возникающая при трогании, в начальный период разгона и торможении. Для уменьшения негативных последствий от таких нагрузок применяются упруго- 
демпфирующие механизмы. Разработкой и изучением их применения, ученые занимаются и сейчас. В настоящей статье был проведен анализ взаимной корреляционной функции и анализ взаимной спектральной плотности двух процессов: частоты вращения коленчатого вала двигателя и частоты вращения ведущего колеса. Этот анализ показывает изменение скорости проходящих частот нагрузки по валопроводу силовой передачи колесного трактора тягового класса 1,4 в силовую передачу которого установлен упруго-демпфирующий механизм. Исследования были проведены для условий работы трактора с сеялкой. Цель исследования заключалась в определении влияние упруго-демпфирующего механизма, установленного в силовую передачу трактора, на его работу с прицепной сеялкой. В общем случае объектом исследования является процесс функционирования трактора тягового класса 1.4, который находится в агрегате с сеялкой. Анализ взаимной корреляционной функции двух процессов показал изменение скорости проходящих частот нагрузки по валопроводу. Отношение времени прохождения сигнала возмущений в опытном тракторе по отношению к серийному варианту по валопроводу при агрегатировании трактора с сеялкой уменьшается на 40,1 \%. Анализ взаимной спектральной плотности показывает смещение частоты возмущающих воздействий по отношению к серийному варианту и уменьшение их величины при агрегатировании трактора с сеялкой на 33,3 \%. Величина взаимной спектральной плотности меньше в опытном варианте трактора, что может означать то, что упруго-демпфирующий механизм, как элемент силовой передачи, поглощает часть колебаний нагрузки и снижает их скорость распространения по валопроводу.

Ключевые слова: динамические прочессы, упруго-демпфирующий механизм, силовая передача трактора, взаимная корреляиионная функиия, взаимная спектральная плотность.

One of the significant factors influencing the operation of the tractor is the unsteady load that occurs when starting off, during the initial period of acceleration and deceleration. The elasticdamping mechanisms are used to reduce the negative consequences of such loads. Scientists still develop and study their application. In this article, the analysis of the cross correlation function and the analysis of the mutual spectral density of two processes were carried out. The analyzed processes were the engine crankshaft speed and the drive wheel speed. This analysis shows the change in the speed of the passing load frequencies along the shaft line of the traction class 1.4 wheeled tractor power transmission, where an elastic-damping mechanism is installed. The studies were carried out for the operating conditions of a tractor with a seeder. The purpose of the study was to determine the effect of the elastic-damping mechanism installed in the power transmission of a tractor on its operation with a trailed seeder. In the general case, the object of research is the functioning of a tractor of traction class 1.4 process, which is located in a unit with a seeder. Analysis of the mutual correlation function of the two processes showed a change in the speed of the passing load frequencies along the shaft line. The ratio of the propagation time of the disturbance signal in the experimental tractor in relation to the production version along the shaft line when aggregating the tractor with the seeder decreases by $40.1 \%$. The analysis of the mutual spectral density shows a shift in the frequency of disturbing influences in relation to the serial version and a decrease in their value when the tractor is aggregated with a seeder by 33.3\%. The value of the mutual spectral density is lower in the experimental version of the tractor, which may mean that the elastic-damping mechanism, as an element of the power transmission, absorbs part of the load fluctuations and reduces their propagation speed along the shaft line.

Keywords: dynamic processes, elastic-damping mechanism, tractor power transmission, cross correlation function, mutual spectral density.

Для цитирования: Сенькевич С.Е., Ильченко Е.Н., Алексеев И.С. Результаты проведения экспериментальных исследований трактора, оснащенного упруго-демпфирующим механизмом при агрегатировании с сеялкой // Тракторы и сельхозмашиныл. 2021. № 4. С. 33-44. DOI: 10.31992/0321-4443-2021-4-33-44

Cite as: S.E. Sen'kevich, YE.N. Il'chenko, I.S. Alekseyev Results of experimental studies 
of a tractor equipped with an elastic-damping mechanism when aggregated with a seeder. Traktory i sel'khozmashiny. 2021. No 4, pp. 33-44 (in Russ.). DOI: 10.31992/0321-4443-20214-33-44

\author{
КАЧЕСТВО, НАДЁЖНОСТЬ \\ QUALITY, RELIABILITY
}

DOI: 10.31992/0321-4443-2021-4-45-54

\title{
Методика численного решения задач применительно к электротеплообменникам типа «змеевик» для подогрева топлива
}

\section{Methodology for the numerical solution of problems in relation to the coil-type electric heat exchangers for heating fuel}

\author{
д.т.н. Крохта Г.М., \\ к.т.н. Хомченко Е.Н., \\ Усатых Н.А.
}

Новосибирский государственный аграрный университет, Новосибирск, Россия, mshipo@mail.ru
G.M. Krokhta, DSc in Engineering

YE.N. Khomchenko, PhD in Engineering

N.A. Usatykh

Novosibirsk State Agrarian University, Novosibirsk, Russia

mshipo@mail.ru

Специфика условий эксплуатации сельскохозяйственных тракторов в условиях АПК требует обеспечения надежного пуска двигателей при низких температурах окружающего воздуха. Улучшения пусковых качеств дизеля и снижения неполноты сгорания в послепусковой период можно достичь путём повышения эксергии воздушного заряда в конце такта сжатия или увеличения эксергии топлива, впрыскиваемого в камеру сгорания. Цель исследования снижение затрат эксергии на предпусковую подготовку дизельного двигателя, повышение пусковых качеств и снижение неполноты сгорания в послепусковой период. Для достижения поставленной цели была разработана конструкция электротеплообменника в виде змеевика из топливопровода высокого давления, в который вставлен нагревательный элемент и разработана методика расчета его основных параметров. Расчеты показали, что для обеспечения надежного пуска дизельного двигателя в зимний период необходимо в режиме термофорсирования нагреть топливо в форсунке до температуры $240^{\circ} \mathrm{C}$. Для достижения такой температуры в течение 270 с предпусковой подготовки требуется нагреватель мощностью около 98 Вт. Однако, для поддержания такой температуры топлива в процессе пуска необходимо внести изменения в конструкцию форсунки с целью максимального снижения потерь тепла в стенки топливного канала путем нанесения теплоизоляционного покрытия. При дальнейшей работе двигателя в режиме послепускового прогрева температуру топлива в форсунке снижают до $85-95^{\circ} \mathrm{C}$.

Ключевые слова: дизельный двигатель, пуск, послепусковой прогрев, температура окружающей среды, электротеплообменник.

The specificity of the operating conditions of agricultural tractors in the agro-industrial complex requires the provision of reliable engine start at low ambient temperatures. Improving the starting qualities of a diesel engine and reducing incomplete combustion in the post-start period can be achieved by increasing the exergy of the air charge at the end of the compression stroke or increasing the exergy of the fuel injected into the combustion chamber. The purpose of the study is to reduce the expenditure of exergy for prestarting a diesel engine, improve starting qualities and reduce 
incomplete combustion in the post-start period. To achieve this goal, the design of an electric heat exchanger was developed in the form of a coil from a high-pressure fuel line, into which a heating element is inserted. A method for calculating its main parameters was developed. Calculations showed that in order to ensure reliable start-up of a diesel engine in winter, it is necessary to heat the fuel in the nozzle to a temperature of $240^{\circ} \mathrm{C}$ in the thermal boost mode. A heater of about 98 Watts is required to reach this temperature within 270 seconds of priming. However, in order to maintain such a fuel temperature during the start-up process, it is necessary to make changes in the nozzle design in order to minimize heat losses into the walls of the fuel channel by applying a heatinsulating coating. With further engine operation in the post-start heating mode, the fuel temperature in the injector is reduced to $85-95^{\circ} \mathrm{C}$.

Keywords: diesel engine, start-up, post-start heating, ambient temperature, electric heat exchanger.

Для цитирования: Крохта Г.М., Хомченко Е.Н., Усатых Н.А. Методика численного решения задач применительно к электротеплообменникам типа «змеевик» для подогрева топлива // Тракторы и сельхозмашиныл. 2021. № 4. С. 45-54. DOI: 10.31992/0321-44432021-4-45-54

Cite as: G.M. Krokhta, YE.N. Khomchenko, N.A. Usatykh Methodology for the numerical solution of problems in relation to the coil-type electric heat exchangers for heating fuel. Traktory i sel'khozmashiny. 2021. No 4, pp. $45-54$ (in Russ.). DOI: 10.31992/0321-4443-20214-45-54

\author{
ЭКОНОМИКА, ОРГАНИЗАЦИЯ И ТЕХНОЛОГИЯ ПРОИЗВОДСТВА \\ ECONOMICS, ORGANIZATION AND TECHNOLOGY OF MANUFACTURING
}

DOI: 10.31992/0321-4443-2021-4-55-62

\title{
Обоснование формы и параметров новых сортировочных устройств для зернистых материалов
}

\section{Justification of the shape and parameters of the new sorting device for granular materials}

д.т.н. Искендерзаде Э.Б.,

Аббасов Б.А.,

Ахмедли Ш.В.,

Исламова У.Р.

Азербайджанский технический

университет, Баку, Республика

Азербайджан

isgenderzadeh@rambler.ru
E.B. Isgandarzada, DSc in Engineering

B.A. Abbasov,

Sh.V. Ahmadli,

U.R. Islamova

Azerbaijan Technical University, Baku, Azerbaijan

isgenderzadeh@rambler.ru

Статья посвящена обоснованию формы и параметров нового сортировочного устройства для зернистных материалов. Обоснована актуальность предлагаемого нового устройства, имеющего большое значение для машиностроительного и сельскохозяйственного производства. Предложена математическая модель сортировки зернистных материалов.

Принимая во внимание актуальность устройства, были обоснованы форма, параметры конструкции и режимы работы различных элементов с различным: ассортиментом сортировки и показателями эффективности. Для этой цели было разработано новое шнековое устройство сортировки, оснащенное различными средствами автоматизации для повышения производительности, и получены удовлетворительные результаты. На данное сортировочное 
устройство, снабженное автоматическим регулятором, получен патент Агентства интеллектуальной собственности Азербайджанской Республики.

Предлагаемое устройство не создает условий для загрязнения производственной площади, отличается конкурентными преимуществами и высокими показателями техникоэкономической эффективности.

Ключевые слова: устройство, обоснование, форма, параметр, новый сортировщикк, пищевое сырье.

The article is devoted to the substantiation of the shape and parameters of a new sorting device for granular materials. It was substantiated the relevance of the new device, which has a great importance for mechanical engineering and agricultural production. A mathematical model for sorting granular materials is proposed.

The shape, design parameters and modes of operation of various elements with different: sorting assortment and efficiency indicators were substantiated taking into account the relevance of the device. For this purpose, a new auger sorting device was developed. It was equipped with various automation devices to increase productivity. The satisfactory results were obtained. This sorting device, equipped with an automatic regulator, received a patent from the Copyright Agency of Azerbaijan Republic.

The proposed device does not create conditions for pollution of the production area, it has competitive advantages and high rates of technical and economic efficiency.

Keywords: device, justification, shape, parameter, new sorting device, food raw materials.

Для цитирования: Искендерзаде Э.Б., Аббасов Б.А., Ахмедли Ш.В., Исламова У.Р. Обоснование формы и параметров новых сортировочных устройств для зернистых материалов // Тракторы и сельхозмашины. 2021. № 4. C. 55-62. DOI: 10.31992/0321-4443-20214-55-62

Cite as: E.B. Isgandarzada, B.A. Abbasov, SH.V. Ahmadli, U.R. Islamova Justification of the form and parameters of the new sorting device for grain materials. Traktory $i$ sel'khozmashiny. 2021. No 4, pp. 55-62 (in Russ.). DOI: 10.31992/0321-4443-2021-4-55-62

DOI: $10.31992 / 0321-4443-2021-4-63-70$

\title{
Интенсификация восстановления деталей гидроаппаратуры железнением в потоке электролита
}

\section{Intensification of the recovery of hydraulic equipment parts by iron in the electrolyte flow}

\author{
д.т.н. Кисель Ю.Е., \\ Симохин С.П., \\ Мурачев С.А. \\ ФГБОУ ВО «Брянский государственный \\ инженерно-технологическийуниверситет», \\ Брянск, Россия \\ Simonin77@mail.ru
}

YU.E. Kisel', DSc in Engineering

S.P. Simokhin,

S.A. Murachev

Bryansk State Engineering and Technological

University, Bryansk, Russia

Simonin77@mail.ru

Предложена технология безваннового железнения деталей в потоке электролита с одновременным гидромеханическим активированием наращиваемой поверхности, показаны ее преимущества перед традиционным видом нанесения покрытий. Изучены структура, некоторые физико-механические и эксплуатационные свойства железных покрытий в зависимости от режимов электролиза и состава электролитов. Показана возможность высокоскоростного 
электроосаждения железа с широким спектром физико-механических свойств. Установлены режимы электролиза, позволяющие получать качественные прочносцепленные «чистые» железные покрытия с износостойкостью в несколько раз превышающей закаленные легированные стали и скоростью роста осадков в десятки раз большей, чем при традиционном железнении. Разработан типовой технологический процесс железнения деталей, который апробирован на примере восстановления золотников гидрораспределителей сельскохозяйственных машин. Предложены конструкции установки и электрохимической ячейки для железнения золотников гидрораспределителей, обеспечивающие оптимальные гидродинамические условия при нанесении покрытий на изношенные поверхности. Приведены рекомендации по постэлектролизной обработке восстановленных деталей железнением. Выполнены стендовые и полевые испытания гидрораспределителей с восстановленными золотниками, которые подтвердили результаты лабораторных исследований, и показали, что за период эксплуатации неисправностей выявлено не было. Технико-экономические расчеты показали высокую эффективность предлагаемой технологии в сравнении с традиционным железнением. Внедрение технологии на производстве позволит сократить производственные площади и затраты времени на восстановление деталей за счет увеличения производительности процесса железения и сокращения числа операций, уменьшить затрат материалов для приготовления электролитов за счет сокращения операции анодной обработки и промывок, повысить надежность технологии за счет улучшения ее структурной схемы.

Ключевые слова: прочность сиепления; микротвердость; износостойкость; технологический прочесс; ячейка.

The technology of bath-free ironing of parts in an electrolyte flow with simultaneous hydromechanical activation of the growing surface is proposed. Its advantages over the traditional type of coating are introduced. The structure, some physicomechanical and operational properties of iron coatings were studied depending on the electrolysis regimes and the composition of electrolytes. The possibility of high-speed electrodeposition of iron with a wide range of physical and mechanical properties is shown. There were shown the electrolysis modes, which make it possible to obtain high-quality strong-adhered pure-iron coatings with a wear resistance several times higher than hardened alloy steels and a precipitation growth rate tens of times higher than with traditional ironing. A typical technological process of parts ironing was developed. It was tested on the example of restoration of hydraulic valve spools of agricultural machinery. The design of an installation and an electrochemical cell for ironing the valve hydraulic distributors, providing optimal hydrodynamic conditions when applying coatings to worn surfaces, was proposed. Recommendations for the postelectrolysis treatment of restored parts by iron are given. Bench and field tests of hydraulic valves with remanufactured valves were carried out. They confirmed the results of laboratory studies, and showed that no malfunctions were identified during the operation period. Technical and economic calculations have shown the high efficiency of the proposed technology in comparison with traditional ironing. The introduction of the technology in production will reduce the production area and the time spent on restoring parts by increasing the productivity of the iron process and reducing the number of operations, reducing the cost of materials for preparing electrolytes by reducing the operation of anodic treatment and washing, and increasing the reliability of the technology by improving its structural scheme.

Keywords: adhesion strength, microhardness, wear resistance, technological process, cell.

Для цитирования: Кисель Ю.Е., Симохин С.П., Мурачев С.А. Интенсификация восстановления деталей гидроаппаратуры железнением в потоке электролита // Tpaкторы $u$ сельхозмашины. 2021. № 4. C. 63-70. DOI: 10.31992/0321-4443-2021-4-63-70

Cite as: YU.E. Kisel', S.P. Simokhin, S.A. Murachev Intensification of the recovery of hydraulic equipment parts by iron in the electrolyte flow. Traktory i sel'khozmashiny. 2021. No 4, pp. 63-70 (in Russ.). DOI: 10.31992/0321-4443-2021-4-63-70 


\section{Исследование непрерывного режима смешивания кормовых компонентов в смесительной установке}

\section{Study of the continuous mode of mixing feed components in a mixing plant}

к.т.н. Солонщиков П.Н.

ФГБОУ ВО Вятский ГАТУ, Киров, Россия, solon-pavel@yandex.ru
P.N. Solonshchikov, $\mathrm{PhD}$ in Engineering

FGBOU VO Vyatskiy GATU, Kirov, Russia, solon-pavel@yandex.ru

В статье рассматривается проблема по разработке средств, которые смогут повысить эффективность механизации процесса приготовления жидких кормов в животноводстве. Конструкторскими бюро, научно-исследовательскими и проектно-технологическими институтами механизации и электрификации сельского хозяйства разработаны новые прогрессивные технологии, а также комплекты, агрегаты, машины и аппараты для животноводства и кормопроизводства. На основе этой техники внедряется комплексная механизация ферм и создаются животноводческие комплексы с индустриальной технологией производства продукции. Но в последнее время широкого применения отечественных машин по приготовлению жидких кормовых смесей не представлено. Поэтому предлагается экспериментальная установка, совмещающая в себе три функции: дозатора, насоса и смесителя, позволяющего в конечном итоге получить смесь хорошего качества. В статье приводится программа и методика исследований установки. Для этого разработан специальный стенд, позволяющий определять параметры качества смеси и удельных затрат электрической энергии. В качестве поиска оптимального сочетания факторов для критериев оптимизации: степень однородности и удельные затраты электрической энергии, был выбран план $3^{2}$. Экспериментальные исследования показали диапазон подачи установки при различных частотах вращения вала рабочего колеса. Исследования по смешиванию подтвердили эффективность конструкции установки и ее составляющих устройств: дозатор, насос и смеситель. С помощью методов планирования эксперимента выделены основные факторы влияющие на процесс смешивания, и определены оптимальные параметры качества смеси. По проведенным исследованиям по непрерывному внесению компонентов в экспериментальной установке для приготовления жидких кормовых смесей, получили что оптимальными сочетаниями факторов будет температура воды $t=$ $26 \ldots 38{ }^{\circ} \mathrm{C}$ и частота вращения $n=1500 \ldots 1650$ мин $^{-1}$, при этом степень однородности достигает $\Theta=94,6 \%$ и удельные затраты электрической энергии $Э_{э л}=0,198$ кВт·ч/т.ед.ст.одн.

Ключевые слова: установка, смесь, температура, частота вращения рабочего колеса, степень однородности, удельные затраты электрической энергии, фактор, жидкие кормовые смеси.

The article discusses the problem of developing means that can increase the efficiency of mechanization of the process of preparing liquid feed in animal husbandry. Design bureaus, research and technological institutes for mechanization and electrification of agriculture have developed new progressive technologies, as well as kits, units, machines and apparatus for animal husbandry and fodder production. On the basis of this technique, complex mechanization of farms is being introduced and livestock complexes with industrial production technology are being created. But recently, the widespread use of domestic machines for the preparation of liquid feed mixtures has not been presented. Therefore, an experimental setup that combines three functions: a batcher, a pump and a mixer is proposed. It ultimately allows to obtain a mixture of good quality. The article provides a program and research methodology for the setup. For this, a special test bench has been developed. It makes possible to determine the parameters of the mixture quality and the specific con- 
sumption of electrical energy. As a search for the optimal combination of factors for the optimization criteria: the degree of homogeneity and the specific consumption of electrical energy, plan $3^{2}$ was chosen. Experimental studies have shown the range of supply of the installation at different speeds of rotation of the impeller shaft. Mixing studies have confirmed the effectiveness of the design of the plant and its components: dispenser, pump and mixer. With the help of experimental planning methods, the main factors influencing the mixing process are identified, and the optimal parameters of the mixture quality are determined. According to the studies of the continuous introduction of components in an experimental setup for the preparation of liquid feed mixtures, it was obtained that the optimal combinations of factors would be the water temperature $t=26 \ldots 38{ }^{\circ} \mathrm{C}$ and the rotation frequency $n=1500 \ldots 1650 \mathrm{~min}^{-1}$, while the degree of homogeneity reaches $\Theta=$ $94,6 \%$ and unit costs of electric energy $\mathrm{E}_{\mathrm{el}}=0.198 \mathrm{kWh} / \mathrm{t} . \mathrm{d}$. h.

Key words: setup, mixture, temperature, impeller rotation frequency, degree of homogeneity, specific consumption of electrical energy, factor, liquid feed mixtures.

Для цитирования: Солонщиков П.Н. Исследование непрерывного режима смешивания кормовых компонентов в смесительной установке // Tракторы и сельхозмашины. 2021. № 4. C. 71-76. DOI: 10.31992/0321-4443-2021-4-71-76

Cite as: P.N. Solonshchikov Study of the continuous mode of mixing feed components in a mixing plant. Traktory $i$ sel'khozmashiny. 2021. No 4, pp. 71-76 (in Russ.). DOI: 10.31992/0321-4443-2021-4-71-76 